\title{
LAW AND/OR SPACE OR WHAT YOU WILL
}

\author{
Yrd. Doç. Dr. Ayşen Furtun \\ Kirıkale Üniversitesi \\ Hukuk Fakültesi
}

\section{Hukuk velveya Mekan veya Ne Derseniz 0̈zet}

"Toplum-Hukuk" ikili örüntüsünün varlığını öncelikle, konuyu realist bir bakış açısıyla ele aldığımızda, "fizik" bir curende kanutlamamız ve bunun üzerine kurgulamamız aynı zamanda bu fizik evrenin kendi fiziki "doğa" sını da ele almayı ve ayrıntılı olarak irdelemeyi gerektirmektedir; bu makalede konu bu çerçevede ele alınmışır.

Buna göre bu fizik doğa yine öncelikle fiziki bir coğrafyayı ve bu coğrafyanın kendi fiziki özelliklerine göre kurgulanan çeşitli tasanmları -, örneğin bircy bazında ikametgah ve mülkiyet, toplumlar bazında, toprağan niteliğinin beraberinde getirdiği ckonomik ve sosyal yaşam biçimleri ve yine bunlar üzerine kurgulanan "siyasal" ve "hukuki" sistemler ve bu arada toprağın ülke ve vatan kavramlarına dönüşmesi gibi-öngörmektedir.

Sonuç olarak "fizik" doğanın kendi bağlamunda, kendi özüne uygun olarak kavranması ve kurgulanması, daha sonraki ikincil örüntü aşamalarında oluşabilecek yanlıs tasarımların önünü kesebilmekte, aksi takdirde söz konusu tasarımların karşıı̆̆ı fizik dünyada estetik uygunsuzluklar, gayrietik sahiplenmeler ve bu yolda savaşım sürecinde insanlık tarihi boyunca harcandığı gözlemlenen insan varlığına ilişkin negatif fizik artı doğa enerjisi şeklinde somutlaşmaktadır.

\section{Abstract}

The "Society-Low" dual pattern, from a realistic point of view, requires for testing its validity a "spatial" referent upon which theorization shall prove itsclf or not!

Yet "space" needs a further referent as "physical component" a geographical coordination observed in peoples' lives either individually as homes or possesssions or socially as in political structures or even before that as an economic source of production the "land" !

Once this referral is not duly done in the physical environment of the people, there follows a continuous struggling process of the beings either as individuals or as socictics fighting against one another to validate their own theorizations without referring to the real physical geographical stances of the issues of concern even trying to implement something impossible that is supposedly faking the true physical referent since luckily in space.

Thus the best example can be found in the border distinctions of presence or yet another half theorized concept of occupation as observed in the "architectural" compositional unity of each pattern. 


\section{Law and/or Space or What You Will}

Human deliberation if we suppose it to confront any such question as "What is society and/or humanity" -regarding ontology -or even before that simply human existence on earth both spiritually and even before that again physically requiring another physical standing or environment together with itself that of a physical world of land finding its definitive outer and innermost sphere in the planet Earth --would formulate -as it did-an interdependence finding its roots as early as in Latin saying "Ib1 societas ibi ius" (Wherever there is a society there is law!) In the same regards Timacheff is quoting that "Almost every social group has its existence within legal space; that is, it is related in a specific way to certain complexes of legal rules." (TIMASHEFF, 1939: 251)

Yet for this interdependence to be observed and therefore to be valid we should first ask "Where do we find this society together with its law?" as for example to study primitive tribes which surely form socictal typologies of ancient living on the planet we have to discover the geography they live on and in and why that particular geography in regards its characteristics and furthermore its definitive boundaries again! Here we have to quote Wigmore stating that "The influence of geography has operated in two ways -immediately, through natural features, and mediately, through race and race traits. The latter form -mediately, through race -has been vital. All except three of the principal legal systems have originated in particular race stocks and have usually taken on their distinctive traits before the race stock had been diluted or the system transplanted." (WIGMORE, 1929: 115)

Natural law theories mostly arising from the idealistic nature of human beings supposing at least a minimum degree of ethical-ideal quality of essence in human homo sapiens in their theoretical boundaries are quite well aware of the fact that their suppositions need not to have certain observable consistency of fact in the real world of physical stance since they have in mind a nature of theoretical assertion whether proven or not! But if we are desperately searching for some reality or that is following another yet major approach to our 
deliberative inquiry mostly labelled as "positivism" or better nominated "realism" any such assertion whether theoretical or not would not suffice in our case. Therefore positivism as a major premise ascribes reality only to those things and relations which have physical standing which may be observed through senses and thus verified.

Thus when we consider a society or a societal group we have to discover first where we can find this society -as an exemplar to physical things having mass and volume- the coordinates of geographical area of this social happening as if asking an individual person's address which differs a legal concept of domicile from ordinary perhaps transitory living place in regards the criteria of continuum whereas one in case of change informs others in order for his social being to be continously acknowledged. In parallel the physical standing that is the geographical land where one tribe or a society lives is rightly to be acknowledged coordinated thus permanently as it is unless gone through change! Thus "Legal concepts and rules have a geographical significance for they often determine the territorial boundaries of homes, courts, electorates and nation states, as well as the status, e.g., nationality, of persons." (KATZ, 1979: 383)

Therefore the social gathering and the land on which this gathering takes place are in actual observable facts interdependent for acknowledgement and what is more inter-coordinated in unity of "physical" and "physical". Only on this physically proven basis of land and human being can any spiritual and ongoing further living of social relations of these physical beings can flourish. As Olivecrona in accordance with his realistic approach has asserted "....a law outside the natural world is inconceivable." (OLIVECRONA, 1939: 15)

Thus in political thinking political structures of whatever type need as a conditio sine qua non this physical space of geographical landing. Furthermore it is obseved in time that on a certain geography certain people living on that geography shape supposed to be different political structures or rather put correctly "transfer one structure into another" through transition. Yet political scientific observation in statistical terms denotes a quite certain permanent pattern of essence present in one geography despite such variety of patterns transient now and then what is more contrasting one another. Quoting Wigmore again "The three exceptions -Maritime, Papal and Romanesque law -have arisen independently of race. The first had a geographical origin, the second a religious, and the third an intellectual." (WIGMORE, 1929: 115

Coming from the traditional dichotomy of labelling, such terms as south-north or east-west --furthermore distiction strengthened by an additive proposition of versus meaning a stronger contradiction rather than any relational unity if any -- have their geographical status of coordinates together with ascribed qualities of social, cultural, economic and the like meanings of 
physical and real essence. But first of all we should first move on as explained above from the physical coordinates as some kind of global address and later on move on to the second stage of theoretical aspiration on a verified physical basis. And one should not be surprised to discover as observation proves that the border distictions between these conflicting dualities both in theoretical concept but long before that in physical geographical standing does not much change despite minor varieties or even in some major coordination stances wrongly claimed to be a general over-all throw of the acknowledged stance of ordination.

At least in a gegraphical alpabet of learning the equator dividing the planet Earth into two main divisions of its two polars -whether contrary to one another or not in the secondary stages of ascription - is a scientific maxim of rational unity. Yet the two poles providing this major distinction in regards the equator--although much less providing the same geographical out-look at the outermost coordinates except this extremity of spheral boundary --proves the distinction at intermediate varying levels verifying a pattern of differing essence than that of the other as observable in climate, topography and the like.

Thus once again building on this geographical elements of uttermost proven generalized certainty, one would not be surprised to discover on the same physical coordinates a different yet merely theoretical certainty of essential ascription: Wherever the land is barren people have to work cooperatively in stronger social bondages considering one another's being in such strengthened structures upon where legal system carries the same characteristics of "sociality" in order to support one and other where there is little room for disregarded, neglected or unexpired areas where everything under these restricted and limited physical and geographical circumstances of living have to be taken into consideration and furthermore have to be used most effectively for everyone's benefit giving the "societal" structure birth and strengthening it and with additive punitive qualities to keep it thus running and furthermore which is easy to be distorted under this fake slogan of "for everyone's benefit" considering merely an average benefit for everyone rather than taking into consideration personal differences. Quoting Hammett "key variables such as need are not easy to measure on a territorial basis since individuals or groups within a designated area are unlikely to have identical, or even similar, needs. To assume that they do is to commit what is sometimes referred to as an "ecological fallacy". (HAMMETT, 1979: ch. 13)

On the other hand whereas the land is fruitful although it may be small, (yet better assumed to be large,bearing its presence within the concept of geographical fruitfulness, richness as well) people have more place (space) of their own furthermore which they have the right to keep away and apart from others in security labelling it their own and where on the macro level the societal living has either conscientiously or -in a fewer less developed stages yet not 
totally flawed as in barrenity- through disregard or neglect opened potential room for any such things as whose physical boundaries shall be drawn by the very individuals of this society of people. Thus Black asserts that "the relationship between law and relational distance is curvilinear. Law is inactive among intimates, increasing as the distance between people increases but decreasing as this reaches the point at which people live in entirely seperate worlds." (BLACK, $1984: 37,41$ )

Now the reflection of this broad exclamation may well find its perspective in another yet major field of ascription of reality such as economics and political structural definitions building on economics such as capitalism again together with liberal political structures of liberal states where any such secured room of undiscovered geography -although arising from a previous major sine qua non condition of fruitfulness or richness - also strengthens it rather than for instance societal-strengthened political structures of "less" in macro level may well decline it going against its essence of original pattern under a fake transformation (cf. the paragraph above).

Moving on further there is still the question of " why people need room, space or place -as you will or what ever you call it - or in many cases "more" of it?" again first starting from the physical meaning of the term space then moving on to the personal sphere of place and room and moving on further asking whether any such demand may rightly or legitimately come from any society or societal living (they know themselves well) depending naturally on its characteristical strong or weak bonded structure such as observed in various wars through out the entire human quest on carth from tribal clashes to nuclear weaponed technology -all this -arising from mere conflict of land that is geographical space and place in our terms? Quoting Schofer "To date the frontiers of the legal system have been understood primarily in jurisdictional terms associated with the legal and political sovereignty of the nation state, even though legal pluralism and supranationalism increasingly render such terms obsolete. Legal systems nevertheless continue to be seen as extending either to the physical boundaries delimiting the territorial competence of the state, these sometimes being the subject of legal disputes which geographical evidence may help to settle, or else as far as law and the state penetrate social relations." (SCHOFER, 1975: 151) (cf. BECKSTROM, 1973)

So what is it -merely a piece of land as a physical entity- that attracts one person or a societal group or a nation that draws that being to itself so strongly that it raises a demolishing clash or a real war in macro level between two wanting parties of the same thing or is it that the meaning they impose on a physical entity such as ownership that makes it so valuable and almost blinding to harm the other for the end of the goal through lackage of true meaning maybe which is actually unattainable for the being as long as the being if one were to 
see it although the physical circumstances may fakely seem to be proving it otherwise (cf. the concluding paragraph for the idea in another "architectural" perspective ).

As a solution inquiries into the problem of "ownership" in legal terms has much less tried to theorize and legalize the problem in regards beings considered within a certain definitive legal system binding all those and those two parties in regards the problem to be solved with a certain and definitive answer to it but yet there is still the international issues of it where there is no such definitive and binding power keeping the parties from wanting something thay do not deserve yet within their physical reach of power sometimes and actually mostly covered under a disguise of legal legitimacy claims of mere ignorance and weakness if not wickedness. Yet again even in certain legal systems with certain definitive solutions the losers of the case are the declared "losers" having gone through the legitimized struggle procedure either being misled by their desires or what? Some kind of attraction, devotion and therefore struggling commitment along with are all "side-theorizations" to the issue awaiting to be illuminated by the realistic and thus "physical" solution to the major problem. Furthermore in some cases the rightful party with the real legitimate claim to the (physical) thing loses the case merely due to the fact that societal structure has long been maneouvred to be running on "supposed" to be "average benefit for everyone" sometimes considering even those who by being misled if not misconducted this time through intellectual poverty has expressed a claim or even struggled earnestly for that very thing.

Again being faithful to our physically verified realistic point of view the need for a room or for any or certain (cf.below) kind of living space for any human-being (actually for any living being including both animals and even-plants that don't move except around themselves ) can easily be recognised in the very actual fact of societal livings of any society under personal or personally formed gatherings as in the form of a family beneath a housing drawing the physical stance and furthermore the boundaries of this time - both physical and social entity bearing a life and a living of its own inside mostly differing from another housing of another family.

Here we have to take into account that the term "housing" before meaning the household or the running of it as mentioned earlier above requires the presence of a physical entity -that of a house- at first hand. Homeless living or "made" to be living outside this sphere is considered everywhere to be a social catastrophe for all kinds of living. This point can be easily thought in relation with the previous point mentioned that of "who will own what" or rather the struggling process resulting in any definitive conclusion to that, the rightly acknowledged or the misled exclamations within the process. So the question at 
this point turns out to be as "why do the homeless not have housing and certainly a "house" within that structure of their own, because someone as in relation to the above mentioned struggle has made them so as being losers to that claim as a conclusion?! (cf. BURRIDGE, 1989)

Yet on the macro level all nations as properly labelled as "a certain societal group of living" have much less a certain piece of land where their national entity of societal living is built upon and furthermore as mentioned in the earlier paragraphs with "a certain essence of permanent pattern". Yet again as the comparison goes in the micro level all individuals are supposed to have a housing, small or big depending on the structural composition of strong or weak bondages as a result of primary conditions of geographical physical stances of "strength" or "poverty" on the macro level. Again we have to consider in both cases in both micro and macro levels the extremity of "homeless" surely presupposing behind the concept of "home" a house of physical stance to be fulfilled both physically and afterwards socially to be a home. This fact actually corresponds to another extremity of social organizational structures such as dormitories, pensions and even hotels or the relation of tenantship and the like where the living pattern is such as "living at present at another's home or part of house" yet exclaiming independence of it both socially and furthermore physically within the "same" structure! In this case is it that the house is a structural abnormality lacking a compositional unity to be a home giving way to such extra-ordinary claims or that there is no house better understood if we refer to the term "home" which could be interrelated with a barren land exemplary above where necessarily strong bondages lead to necessarily close yet much "partial" structuring where everyone much less owns what he/she shares as an average with the rest of the owners.

Again in the same parallel one can inquire as an answer to the main problem we mentioned in the earlier paragraphs that in the case of "wars" on the macro societal that is national level or again in the micro level of individual exclamations of "ownership" toward this or that thing is it that "all that happens is actually. the struggle for the pull-down of one such organizational structure symbolising as in the examples a certain societal pattern of living under whatever political structure one can label it and instead building up of individual houses to be homes yet still as a true respond to the lackage of enough physical geographical space peoples claims to the ownership are in actual facts the legitimate ones and that no such misled claim may succeed under a fake struggle for righteousness.

As a conclusion thus taking the above mentioned inquiry as a resolving point and relating this final point with our initial point of geographical physical certainties leading to much less the same certainties of parallel structuring of societal living upon them in order to avoid wars or social clashes or even merely 
conflicts of opinion we have to have and what's more secure and strengthen certain patterns which are also observed as factual data and even as simply as "certain houses of our own to be homes" and furthermore "permanently and also acknowledged by the others permanently". For this purpose we have to know again both the outer and the inner structure of our houses to be homes such as the physical material structure the house is built up and also the architectural design or pattern of it and thus don't be misled by others who claim either through "power"-as in the case of wars outside the legal sphere- or "persuasion" -as in the case of ownership within legal sphere- the right to transfer or better nominated with a fake smooth term of "change" it to something with neither inner nor outer structure of real physical stance.

As to the vital issue whether the societal party starting up the conflict raging from mere strife to war wanting "more" and furthermore others' share together with its own or even sometimes leaving his/her own somehow and wanting others as being drawn to it by misleading oneself and sometimes taking many others behind its back is actually -in actual fact- "right" or "wrong" has again a certain definitive answer; I will use the exemplary of "architecture"al structuring to simplify actually the already certain answer for general acknowledgement: As mentioned one of our initial points the "distinctions" are actually the borders or boundaries of both theoretical but before that physical ascriptions. Therefore as a certain pattern of any such distinctive theoretization "architecture" and its definitive binding borders differing one pattern of building from another both in time schedule and within the same time period bears the answer to the question who is right to the ownership of any physical thing; house, land whatever through the struggling of conflict, clash or war and what is more up to what extent, that is again where to draw the boundary between the two distinctions.

So today in verification of our assertions most of the classical architecture of any societal living has been distorted or even in some cases wholly destructed and furthermore exchanged with that of another pattern as in our exemplaries above e.g. that of the change of economic systems without regarding the fruitfulness or the barenity of the land just for the sake of mere "change" (the smooth term) rather than any essential need for it.As a result we have ugly architectural structures or badly run economies as a total destruction and as a partial one we have the classical pattern in "few" in "minority" yet alas together "with" the supposed to be new transformed structuring as in the above mentioned case of one's using some rooms of his/her house-home as pension or the like etc. but rather "leaving "the authority, the needs of the running of the pension.

The last inquiry is whether the "classical" may have room within itself for the "new" as in the exemplar of fruitful land opening and securing room for 
personal creativity and thus differences, but that again can only be possible within the "whole" architecturing of the system not a "montage" or a "collage" to it as in the suitably matched exemplar of having classically architectured buildings but having modern inner structure within yet not distorting the "pattern" always keeping to the original structural "composition".

Thus as one last final point we must conclude that the certain patterns of ascription even within pure verification can not be stretched over their real physical geographical borders that is the "distinctions" and whether certain conflicts of claims on where these distinctions start have any factuality shall be determined in the physical world again within the physical and theorctical boundaries of "space" obscrvable in our ownership of architectural structures of acknowledged "essence" or instead ugly buildings and surroundings...

\section{References}

BECKSTROM. J.H. (1973). "Transplantation of Legal Systems:an early report on the reception of Western laws in Ethiopia," American burnal of Comparative Law. 21.

BLACK. D. (1984). "Social Control as a Dependant Variable." BLACK. D. (ed.), Touards a Ceneral Theory Of Social Control (New York, London: Academic Press).

BURRIDGE. R. (1989). "Housing tales of law and space," .kumtal of Liw and Society. 16.

HAMMETT.C.(1979) "Area-based explanations." HERBERT. D.T./SMITH.D.M. (eds.), Social Problems and the City: geographical perspectives (Oxford, New York :Oxford University Press).

KATZ. A. (1979). "Studies in Boundary Theory." Buffalo Law Review, 28.

OLVECRONA. K. (1939), Law As Fact (London: Oxford University Press).

SCHOFER. J.P. (1975). "Territoriality at the micro, meso and macro scales," Jourrial of Ciecxyraphy, 74.

TIMASHEFF. N.S. (1939). An Introduction to the Sociology of Law (Cambridge: Harvard University Committee on Research In the Social Sciences).

WIGMORE. J. H. (1929), "A Map of the World's Law." Gecographical Review, 19 